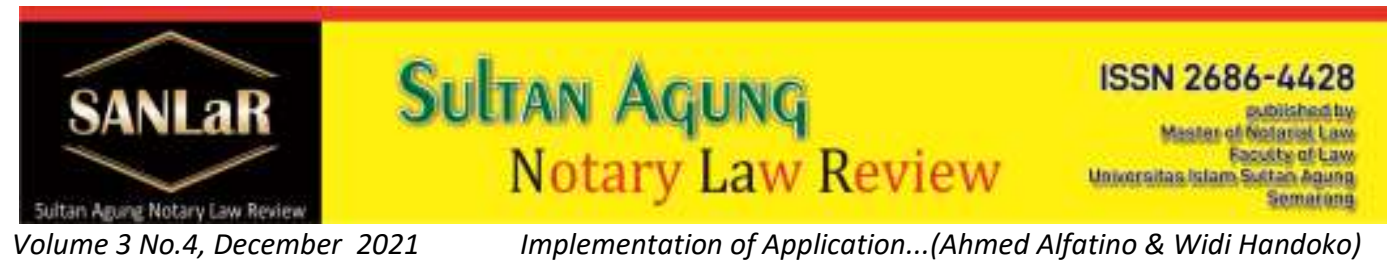

\title{
Implementation of Application of Mortgage Rights Electronically
}

\author{
Ahmed Alfatino*) and Widi Handoko**) \\ ${ }^{*}$ Faculty of Law, Universitas Islam Sultan Agung (UNISSULA) Semarang, E-mail: \\ ahmed.alfatino@gmail.com \\ *) Faculty of Law, Universitas Islam Sultan Agung (UNISSULA) Semarang, E-mail: \\ widhihandoko@unissula.ac.id
}

\begin{abstract}
The purpose of this research is to find out and analyze the implementation of mortgage rights electronically in the conception of legal certainty. To find out and analyze the effectiveness of the implementation of mortgage rights electronically. The method used by the researcher is Juridical Empirical (sociolegal research) and the specifications in this study are descriptive analytical. Based on the results of the study that Implementation of Electronic Mortgage Implementation in the Conception of Legal Certainty is that the Granting of Mortgage shall be registered at the Land Office no later than 7 (seven) working days after the signing of the Deed of Granting of Mortgage. The obligation of PPAT to register the Deed of Granting Mortgage at the latest 7 days after being signed as mentioned above has not been running properly. In its implementation, it is still experiencing difficulties caused by the lack of socialization to Registrants regarding the application of the electronic system. The Effectiveness of the Implementation of Mortgages Electronically is that with the electronic-based policy, it is very effective and efficient for all related parties, namely the Community, PPAT, Banks, and the Government in the Mortgage Registration process.
\end{abstract}

Keywords: Dependents; Electronic; Implementation; Right.

\section{Introduction}

In the current era of technology and information, it encourages increased development in all fields. One of the improvements in national development is the development of industrial and trade activities. The increase in industrial and trade activities resulted in an increase in the capital sector in business development. While not all entrepreneurs have sufficient capital to expand their 
business, this is where many transactions in daily life are created in the form of credit or loans.

Computer network technology is growing rapidly marked by the existence of a LAN (Local Area Network) which is a network in the local area and a larger computer network called a WAN (Wide Area Network). ${ }^{1}$ In general, the rapid development of the internet has also led to various legal disputes and conflicts which are quite serious for its users, with many unexpected problems that have appeared in the last few years. This is due to the rapid acceleration in the field of information technology. One of them is the unexpected progress in forms of ecommerce, including e-governance. Transactions conducted through the internet in Indonesia at the conventional level have not been fully covered by law. ${ }^{2}$ The enactment of Act No. 19 of 2016 concerning Amendments to Act No. 11 of 2008 concerning Electronic Information, becomes the basis for the implementation of an Electronic system in Indonesia.

With regard to the practice of granting credit with guaranteed land rights, a guarantee rights institution is needed that is able to provide legal certainty for interested parties in creating a prosperous, just and prosperous society in accordance with Pancasila and the 1945 Constitution of the Republic of Indonesia. Act No. 4 of 1996 concerning Mortgage on Land and Objects Related to the Land or abbreviated as "UUHT" was then formed to meet the needs of the community regarding this matter. ${ }^{3}$ In this regard, in the development of Mortgage Rights in Indonesia, the Government provides services including the electronically integrated registration of Mortgage Rights based on the Regulation of the Head of the National Land Agency Number 9 of 2019 and Permen ATR/BPN Number 5 of 2020 concerning Electronic Mortgage Services and/or thereafter called "HT-el".

Mortgage registration itself is an obligation, it can be found in the formulation based on Article 13 of the Mortgage Law which states that Mortgage Rights are born at the time of Mortgage registration in the Land Book of land rights that are charged with Mortgage Rights. ${ }^{4}$

The owner of the right, or who obtains further rights through the encumbrance of the right, is given a certificate which is a certificate of title which is a copy of the register. Issuance of a Mortgage Certificate as evidence of the existence or

\footnotetext{
${ }^{1}$ Anggara, et.al., (2010), Kontroversi UU ITE: Menggugat Pencemaran Nama Baik di Dunia Maya, Jakarta: Penebar Swadaya, p. 3.

${ }^{2}$ Iman Sjahputra, (2002), Problematika Hukum Internet Indonesia, Jakarta: Prenhallindo, p. 5.

${ }^{3}$ Eugenia Liliawati Mulyono, (2003), Tinjauan Yuridis Undang-undang Nomor 4 tahun 1996 tentang Hak Tanggungan dalam Kaitannya dengan Pemberian Kredit oleh Perbankan, Jakarta: Harvarindo, p. 1.

${ }^{4}$ Gunawan Widjaja-Kartini Mulyadi, (2008), Hak Tanggungan, Jakarta: Kencana, p. 213
} 
existence of a Mortgage is regulated in the provisions of Article 14 of the Mortgage Law.

According to Suyus Windayana, as the Director General of Agrarian Legal Relations, what causes Indonesia to be in 6th place based on the ease of doing business index of the World Bank Survey every year In 190 countries, this is due to the relatively high transactional side of documents that are still managed, all of which are still in the form of manual, and not all land midwives are registered..$^{5}$

\section{Research Methods}

In conducting this research, the author uses the empirical juridical method, namely discussing the facts or data that exist in practice, to be further linked to juridical facts. ${ }^{6}$ This research can be classified as descriptive research, which is a research that is intended to provide data that is as accurate as possible about humans, circumstances or other symptoms. ${ }^{7}$ The sources and types of data in this study are primary data. And secondary data obtained from literature studies related to the theory of legal certainty and the theory of legal effectiveness

\section{Results and Discussion}

\subsection{Implementation of Mortgage Rights Electronically in the Conception of Legal Certainty}

In today's digital era, humans in general have a new lifestyle which cannot be separated from all-electronic devices. Technology is now a tool that can help most of human needs. Edmon Makarim argues that naturally, humans cannot be separated from technological advances, whose goal is to facilitate their lives. ${ }^{8}$

Land guarantee institutions can provide strong legal certainty to protect both creditors and debtors, namely Mortgage Rights. Mortgage rights are security rights that are imposed on land rights. Basically a mortgage is a right that has a principal agreement, what is meant by the principal is a debt agreement or credit agreement. In this case the debt agreement or credit agreement is a guarantor of Mortgage Rights which can be said to be guaranteed rights that are not born from law but are born from an agreement. Therefore, the creditor and the debtor must make an agreement in advance in the debt agreement or in the

\footnotetext{
${ }^{5}$ https://kominfo.go.id/content/detail/21128/kementerian-atr/bpn-launchjasaelektronik/0/berita, accessed on May 16, 2021, at 20.13 WIB

${ }^{6}$ Ibid, p. 51

${ }^{7}$ Khuzdaifah Dimyanti, (2004), Metode Penelitan Hukum, Surakarta: UMS-Pers, p. 3

${ }^{8}$ Edmon Makarim, (2004), Kompilasi Hukum Telematika, Jakarta: Raja Grafindo, p. 7
} 
credit agreement that the object of the guarantee will be charged to the mortgage.

The role of a Notary in Mortgage is to match it according to the original letter and make a Power of Attorney for Imposing Mortgage (SKMHT) while PPAT in Mortgage according to UUHT is appointed as an official to make APHT.5 In the prevailing laws and regulations, PPAT is the authorized official to make a deed of transfer of land rights and other deeds in which the form of the deed has been determined. The PPAT deed is a tool to prove that a legal act has been committed. ${ }^{9}$ In granting the Mortgage, the Mortgage giver must be physically present before the PPAT, if the Mortgage giver is unable to attend alone, the Mortgage giver must give power of attorney to another party as his proxy with a Power of Attorney for Imposing Liability Rights (SKMHT) and this letter is made with Notarial Deed. ${ }^{10}$

Mortgage, to register a mortgage is intended to guarantee legal certainty to the giver and recipient of the mortgage and to provide legal protection when one party takes actions that harm the other party. For example, when the mortgage provider cannot pay off the debt he borrowed from the mortgage holder, then with the registration of the mortgage, the mortgage holder has strong legal power to get payment for his receivables by executing the land that is burdened with the mortgage. In order for the creditor to have a priority position, based on the SKMHT, it is followed up with the making of APHT and immediately registered with the local land office with the aim of obtaining certainty of the debtor's debt repayment guarantee. In addition to giving priority to creditors, registration of mortgage rights is a manifestation of the principle of publicity. APHT registration to the land office where the land is located. With the registration of mortgage rights, a certificate of mortgage is issued. ${ }^{11}$

The implementation of the HT-el system is carried out by the land office in stages according to the readiness of supporting data. One of the types of mortgage services that can be submitted through the HT-el system is registration of mortgages. In addition, this system also serves the transfer of mortgage rights, changes in creditor names and the abolition of mortgage rights.

The technical instructions contain the stages for registering Mortgage Rights electronically. What is meant by the stages are partner account registration, account verification, login menu, registration process, file confirmation process,

\footnotetext{
${ }^{9}$ Setyaningsih, Anis Mashdurohatun, Peranan Notaris Dalam Pembuatan Akta Pemberian Hak Tanggungan (APHT) Terhadap Perjanjian Kredit Antara Kreditur Dan Debitur Dengan Jaminan Hak Tanggungan Di Purwokerto, Jurnal Akta, Vol. 5 No 1

${ }^{10}$ Adrian Sutedi, (2010), Hukum Hak Tanggungan, Jakarta: Sinar Grafika, p. 51

${ }^{11}$ Urip Santoso, (2015), Pendaftaran dan Peralihan Hak Atas Tanah Kencana, Jakarta: Prenanda Media Group, p. 65.
} 
payment process, data correction process, certificate printing process, and Mortgage documents. In UUHT that requires Mortgage to be registered at the Land Office. Due to fulfill one of the principles of Mortgage, namely the principle of publicity. That the registration of the Mortgage is an absolute requirement for the birth of the Mortgage and binding the Mortgage to a third party, or in other words, the creditor has a position of preference.

Implementation of Electronic Mortgage in the Conception of Legal Certainty is that the Granting of Mortgage shall be registered at the Land Office no later than 7 (seven) working days after the signing of the Deed of Granting of Mortgage. The obligation of PPAT to register the Deed of Granting Mortgage at the latest 7 days after being signed as mentioned above has not been running properly.

According to the author, Implementation of the implementation of mortgage rights electronically in Sukoharjo Regency in the Concept of Legal Assurance is analyzed using the theory of legal certainty that the existence of general rules makes individuals know what actions may or may not be carried out, and secondly in the form of legal security for individuals from government arbitrariness because of the general nature of rules that individuals can know what the state may charge or do to individuals. Legal certainty is not only in the form of articles in the law, but also consistency in the decisions of other judges for similar cases that have been decided. Legal certainty has two aspects. First, regarding the matter of determining the law (bepaalbaarheid) in concrete money matters. This means that parties seeking justice want to know what the law is in a particular case, before starting a case. Second, legal certainty means legal security.

\subsection{The Effectiveness of the Implementation of Mortgages Electronically}

Legal Effectiveness Theory is a theory that examines and analyzes the success, failure and influencing factors in the implementation and application of the law. There are three focuses of the study of legal effectiveness theory, which include: 1. Success in implementing the law; 2. Failure in its implementation; and 3. Factors that influence it.

Notary as one of the legal professions is one of several elements in the implementation of law which part of its authority ${ }^{12}$ is to issue a document in the form of a deed with the power as an authentic deed. Authentic deed is a deed

\footnotetext{
12 Ong Argo Victoria, Ade Riusma Ariyana, Devina Arifani. (2020). Code of Ethics and Position of Notary in Indonesia. Sultan Agung Notary Law Review 2 (4), 397-407, http://lppmunissula.com/jurnal.unissula.ac.id/index.php/SANLaR/article/view/13536
} 
made and inaugurated in legal form, by or before public officials, who are authorized to do so at the place where the deed was made. ${ }^{13}$

The authentic nature of this deed is an element that fulfills the desire for the realization of legal certainty. The authentic deed itself contains a statement of the rights and obligations of a person or individual (in the civil sector) and therefore protects a person in that interest. ${ }^{14}$

Based on the authority of a notary as referred to in Act No. 2 of 2014 concerning Amendments to Act No. 30 of 2004 concerning the Position of a Notary (hereinafter referred to as UUJN) with his profession as an authentic deed maker accompanied by the rapid and dynamic development of community needs, has increased the intensity and the complexity of legal relations which of course require certainty, order, and legal protection with the core of truth and justice. This is the philosophical basis for the formation of the UUJN through products issued by a notary, namely an authentic deed to ensure legal certainty and legal protection for every user of Notary services. The provisions of Article 1868 of the Civil Code which confirms that: ${ }^{15}$ The role of a Notary is very much needed by the bank, this is also related to the legal risk of the mortgage loan collateralized by the debtor as credit guarantee. ${ }^{16}$

The substance of APHT is regulated in Article 11 of the Mortgage Law. APHT registration is formulated in Articles 13 to 14 of the Mortgage Law. After the APHT is made by PPAT and then signed by the parties, then the APHT together with the warkah and certificates of proof of land rights are registered at the local land office. Failure to record will result in the invalidity of the legal actions desired by the parties against third parties. Third parties may believe in publications that have been made, records in publications cannot be used to harm the rights and interests of third parties in good faith. ${ }^{17}$ This right means that publication and recording are ignored, so the parties cannot postulate the relationship that exists between the parties to third parties. Based on the explanation above, it can be conveyed that the granting of mortgage rights can be done in two ways, namely the granting of mortgage rights with SKMHT which

\footnotetext{
${ }^{13}$ M. Yahya Harahap, (2006), Pembahasan, Permasalahan dan Penerapan KUHAP, Sinar Grafika, Jakarta: Edisi Kedua, p. 76.

14 Dessy Andiyaningsih, Umar Ma'ruf, 2018, Pengalihan Hak Tanggungan Pada Perbankan Di Kabupaten Banjarnegara, dalam Jurnal Akta Vol 5 (1), Unissula, p. 91-92

${ }^{15}$ Wiranto, Maryanto, 2017, Akibat Hukum Penandatangan Perpanjangan Akta Kuasa Membebankan Hak Tanggungan Yang Dibuat Oleh Notaris Tanpa Menghadirkan Kembali Para Pihak, dalam Jurnal Akta, Vol. 4 (4), Unissula, p. 674

${ }^{16}$ Efty Hindaru Sudibyo, Amin Purnawan, 2017, Peran Notaris Dalam Pembuatan Akta Izin Roya Hak Tanggungan Karena Hapusnya Hutang Dalam Perspektif Kepastian Hukum, dalam Jurnal Akta Vol. 4 (2), Unissula, p. 185

${ }^{17}$ Kartini Muljadi \& Gunawan Widjaja, (2003), Kebendaan Pada Umumnya, Jakarta: Prenada Media, p. 67
} 
is then followed by APHT, and secondly with APHT. The APHT together with the warkah and certificates of proof of land rights are registered at the local land office no later than 7 (seven) days after being signed. The National Land Agency makes a mortgage book and records it in the land title book which is the object of the mortgage and copies the notes on the certificate of the land right in question. ${ }^{18}$

The implementation of the making of the Deed of Granting Mortgage to the Bank cannot be separated from the role of the Notary and the Land Deed Making Officer (PPAT). Activities between the bank and the debtor who make the transfer of the Mortgage Guarantee are very interested in making an agreement between them. From the banking point of view, the Notary deed is a strong evidence and is a protection for the bank in the credit agreement as the main agreement of the Mortgage Guarantee agreement. ${ }^{19}$

The presence of an online system should make a job easier, faster and more effective. Effectiveness is how far the achievement of a predetermined goal. Effective in short means its effect, effect, or effect. In this thesis, the effectiveness discussed is the PPAT in assisting the implementation of their duties, namely carrying out some land registration activities, specifically the second land registration. Because one of the purposes of the Land Office Online Service Application is to facilitate PPAT's work. The convenience provided by online-based land management should actually be felt by all PPATs, but it seems that this is not possible because the expected convenience is not optimal in practice.

Effectiveness of Electronic Mortgage Implementation in Sukoharjo Regency is that with the electronic-based policy, it is very effective and efficient for all related parties, namely the Community, PPAT, Banks, and the Government in the Mortgage Registration process.

In principle, a guarantee tied to a mortgage will be effective when the debtor is at a substandard stage in fulfilling his obligations to the creditor. This can be seen from the efforts made by the creditor together with the guarantor to take certain actions aimed at returning the guarantor's position to be smooth. One of them is in the implementation of the execution of mortgages regulated in the laws and regulations in Indonesia, including the aspect of collateral in the form of

\footnotetext{
${ }^{18}$ Ariel Doni Dharmawan, Maryanto, 2018, Kekuatan Hukum Sertifikat Hak Tanggungan Dalam Hal Musnahnya Obyek Hak Tanggungan Karena Bencana Alam Di Kabupaten Grobogan, dalam Jurnal Akta Vol 5 (1), Unissula, p. 170

${ }^{19}$ Sulistiani, Jawade Hafidz, 2017, Kerjasama Notaris PPAT Terhadap Bank Di Dalam Pembuatan Akta Pemberian Hak Tanggungan, dalam Jurnal AKta, Volume 4 (4), Published by Master Of Notarial Laws, Faculty of Law Unissula, http://jurnal.unissula.ac.id/index.php/akta/article/view/2514/1877
} 
mortgages in a debt-receivable agreement which is a very important factor where the condition for the execution of mortgage auctions must be a certificate of mortgage.

According to the author, the Effectiveness of Electronic Mortgage Implementation in Sukoharjo Regency is analyzed using the legal effectiveness theory that one of the functions of law, both as a rule and as an attitude or behavior is to consider human behavior, the problem of legal influence is not only limited to the emergence of obedience or obedience to the law, but includes the total effect of the law on attitudes or behavior, both positive and negative.

\section{Conclusion}

Implementation of Mortgage Rights Electronically in the Conception of Legal Certainty bthat the Granting of Mortgage shall be registered at the Land Office no later than 7 (seven) working days after the signing of the Deed of Granting of Mortgage. The obligation of PPAT to register the Deed of Granting Mortgage at the latest 7 days after being signed as mentioned above has not been running properly. In its implementation, it is still experiencing difficulties caused by the lack of socialization to Registrants regarding the application of the electronic system and Effectiveness of Electronic Mortgage Implementation is that with the electronic-based policy, it is very effective and efficient for all related parties, namely the Community, PPAT, Banks, and the Government in the Mortgage Registration process.

\section{References}

Journal:

[1] Ariel Doni Dharmawan, Maryanto, 2018, Kekuatan Hukum Sertifikat Hak Tanggungan Dalam Hal Musnahnya Obyek Hak Tanggungan Karena Bencana Alam Di Kabupaten Grobogan, dalam Jurnal Akta Vol 5 (1), Unissula

[2] Dessy Andiyaningsih, Umar Ma'ruf, 2018, Pengalihan Hak Tanggungan Pada Perbankan Di Kabupaten Banjarnegara, dalam Jurnal Akta Vol 5 (1), Unissula

[3] Efty Hindaru Sudibyo, Amin Purnawan, 2017, Peran Notaris Dalam Pembuatan Akta Izin Roya Hak Tanggungan Karena Hapusnya Hutang Dalam Perspektif Kepastian Hukum, dalam Jurnal Akta Vol. 4 (2), Unissula 
[4] Ong Argo Victoria, Ade Riusma Ariyana, Devina Arifani. (2020). Code of Ethics and Position of Notary in Indonesia. Sultan Agung Notary Law $\begin{array}{lllll}\text { Review } & 2 & \text { (4), 397-407, http://lppm- }\end{array}$ unissula.com/jurnal.unissula.ac.id/index.php/SANLaR/article/view/13536

[5] Setyaningsih, Anis Mashdurohatun, Peranan Notaris Dalam Pembuatan Akta Pemberian Hak Tanggungan (APHT) Terhadap Perjanjian Kredit Antara Kreditur Dan Debitur Dengan Jaminan Hak Tanggungan Di Purwokerto, Jurnal Akta, Vol. 5 No 1

[6] Sulistiani, Jawade Hafidz, 2017, Kerjasama Notaris PPAT Terhadap Bank Di Dalam Pembuatan Akta Pemberian Hak Tanggungan, dalam Jurnal AKta, Volume 4 (4), Published by Master Of Notarial Laws, Faculty of Law Unissula,http://jurnal.unissula.ac.id/index.php/akta/article/view/2514/18 $\underline{77}$

[7] Wiranto, Maryanto, 2017, Akibat Hukum Penandatangan Perpanjangan Akta Kuasa Membebankan Hak Tanggungan Yang Dibuat Oleh Notaris Tanpa Menghadirkan Kembali Para Pihak, dalam Jurnal Akta, Vol. 4 (4), Unissula

Books:

[1] Adrian Sutedi, (2010), Hukum Hak Tanggungan, Jakarta: Sinar Grafika

[2] Anggara, et.al., (2010), Kontroversi UU ITE: Menggugat Pencemaran Nama Baik di Dunia Maya, Jakarta: Penebar Swadaya

[3] Edmon Makarim, (2004), Kompilasi Hukum Telematika, Jakarta: Raja Grafindo

[4] Eugenia Liliawati Mulyono, (2003), Tinjauan Yuridis Undang-undang Nomor 4 tahun 1996 tentang Hak Tanggungan dalam Kaitannya dengan Pemberian Kredit oleh Perbankan, Jakarta: Harvarindo

[5] Gunawan Widjaja-Kartini Mulyadi, (2008), Hak Tanggungan, Jakarta: Kencana

[6] Iman Sjahputra, (2002), Problematika Hukum Internet Indonesia, Jakarta: Prenhallindo

[7] Kartini Muljadi \& Gunawan Widjaja, (2003), Kebendaan Pada Umumnya, Jakarta: Prenada Media 
[8] Khuzdaifah Dimyanti, (2004), Metode Penelitan Hukum, Surakarta: UMSPers

[9] M. Yahya Harahap, (2006), Pembahasan, Permasalahan dan Penerapan KUHAP, Sinar Grafika, Jakarta: Edisi Kedua

[10] Urip Santoso, (2015), Pendaftaran dan Peralihan Hak Atas Tanah Kencana, Jakarta: Prenanda Media Group

Internet:

https://kominfo.go.id/content/detail/21128/kementerian-atr/bpnluncurkan-layananelektronik/0/berita, accessed on 25 September 2021, at 20.13 WIB 